\title{
Introduction: structural reform and competitiveness - the position and future of an integrated Europe
}

\section{Gertrude Tumpel-Gugerell and Peter Mooslechner}

In trying to analyse the position Europe is in today, one has to take note of the fact that after the devastations of World War II and in the 45 years that have passed since the signing of the Treaty of Rome, Europeans have accomplished great economic success and European integration has made huge strides forward.

The European Union will soon consist of 25 member states extending the zone of peace and stability far into the continent, finally repealing an artificial barrier across Europe that had been imposed by the Cold War.

In comparison to the USA the European Union is often criticized for being less dynamic and competitive. But let us not forget the fact that Europe places much more importance on values like social security, lower crime rates and a more equal income distribution. Geographic and cultural heterogeneity enriches the Union, but, of course, constitutes a certain obstacle to labour mobility. Coordinating the political decision making process among 25 member states is certainly a more difficult process than in the US with its homogeneous economic and political structures.

On the other hand, a major compromise on agricultural issues and structural and cohesion funds was reached at the 2002 Brussels European Council and confirmed at the Copenhagen Council in December 2002. This decision confirmed the ability of the EU member states to resolve important issues in a pragmatic and expedient way. As a result of this breakthrough, enlargement is now within reach. We are approaching a historic event when the division of Europe will finally be overcome and the continent united. The gap between East and West has already become smaller and is about to disappear completely, as we are witnesses to Western and Eastern Europe growing together economically as well as politically.

When benchmarking the EU and its member states' economies, it may not be wise to look too much towards the US, but rather to concentrate on highly successful countries in Europe, like Finland or Ireland. In fact, 
processes set up in the framework of the Lisbon strategy provide such an approach via peer pressure and intra-EU benchmarking.

The Lisbon summit of the Union in 2000 committed to an acceleration in the pace of reform by agreeing on a European growth strategy, the ambitious aim being to turn the EU into the world's most dynamic and competitive knowledge-based economic area by 2010. In her contribution, Professor Rodrigues of the University of Lisbon, who was one of the coarchitects of this strategy, deals in more detail with this undertaking, which is known as the Lisbon process.

Of course, there are some areas where particular scope for structural reform in Europe exists:

- Further integration of financial and product markets at the European level is an important measure to enhance competitiveness in Europe. For example, national insurance, banking, and car markets continue to be shielded from within-EU competition. And economic efficiency will be increased, if competition on a European scale contributes to sustained lower prices in these industries.

- On the regional and local level, measures increasing product market competition should be taken. Reducing entry barriers and facilitating administrative procedures for start-up companies will create a more competitive market environment and increase economic efficiency at the local and regional level.

- Besides regulatory measures to increase demand and supply for risk financing, economic policy can also promote firm creation and market entry by facilitating administrative procedures and directly providing start-up finance. Measures in this direction have been taken and partly replace the lack of market-based innovation finance.

- Infrastructure investment is another area in which policy needs to be active. Providing households and firms with access to modern, high capacity telecommunication networks is a key issue in promoting new industries.

- A key factor for increasing productivity, employment and competitiveness is provided by a productive research and education system.

There are three different dimensions that need to be addressed:

1. Education systems need to be flexible and innovative, offering access to new skills and technologies for everyone. The supply of education needs to be oriented towards the demand for skills in the labour market and the use of new technologies in the work process.

2. Research institutions should be more integrated on a European level. 
Strengthening network externalities in the research sector will speed up the creation and distribution of knowledge and promote scientific progress.

3. The system of higher education should promote links between the research institutions and industry. Direct transfer of knowledge from research institutions to firms is often difficult, but can be facilitated by promoting the exchange of information through joint projects, young researchers visiting companies and companies actively seeking input from research institutions.

In the end, addressing these issues will be essential to Europe's future and its possible position in 2020, although thinking about Europe's position in about 20 years is not an easy task. Where might Europe stand in 20 years from now?

- The enlarged European Union of 2020, comprising close to 30 member states, will have unfolded its immense economic and cultural potential.

- Reforms of the economy in the countries that joined the EU in 2004 will have led to a new economic structure where services have become much more important compared to agriculture or industrial production.

- The process of change was not without pain, but unemployment rates were brought down, economic growth has picked up and an investment boom has set in, targeting new markets in still developing regions at the borderlines of the EU.

- All member states of the European Union are also members of the economic and monetary union and an Englishman will become President of the European Central Bank.

- A new institutional framework will be in place in the European Union where European thinking is the guiding light. An elected European government closely cooperates with a European Parliament that plays an important role in the legislative process.

- The monetary union has become an economic and monetary union where economic policy speaks with one voice and where it can operate much more effectively on the ground of a large and rather closed economic area.

- National borders play a less important role and social, economic and cultural regions develop in a more natural way.

A Europe of this kind will probably not be in place in 2020 in exactly the way as described right now, but this is a possible scenario where things 
might go from here. What is important, though, is to develop a vision of the Europe we would like to see in 20 years from now and what we believe to be the best investment in the future:

- to improve the skills of human capital and reform the educational systems;

- to increase the share of public and private investment in research and development;

- to further develop new technologies that assist in overcoming barriers in distance and time and thus to increase the possibility of substantially improving the productivity of the European economies.

A very wide range of issues need to be touched on dealing with macroeconomic and structural problems in the EU and in the accession countries of Central and Eastern Europe, questions that are topical at the moment and that are essential in the medium to long term. Given the goals highlighted in the Lisbon strategy, Europe still has a lot of work to do. There are deficits in market integration and there is scope for structural reform.

- The European financial system remains largely fragmented. To accomplish a truly unified financial system, remaining regulatory, tax and legal barriers need to be lowered. Common standards would increase cross-border confidence of investors. European capital markets should become wider and deeper and thereby unleash growth potential.

- Financial sector integration points to the need for close cooperation among national supervisors and among central banks in preventing and managing financial crises. Supervision at the national level accompanied by European coordination appears to be the most efficient solution, given that national bodies dispose of long-term experience and knowledge of agents and customs in their home markets.

- Europe needs integrated markets for risk capital, because the latter would nurture entrepreneurs and stimulate the introduction of new technologies.

Addressing the difficulties for current labour market, taxation and social welfare regulations is also a key issue in the next two decades.

- The slow growth of labour supply will contribute to improve Europe's unemployment problem, especially if additional measures to promote mobility and increase labour market skills of unemployed workers are 
taken. At the same time, it is likely that average output growth will be lower in the future since employment growth will slow down. Without some adjustment (such as increasing migration), this will lead to financing problems of pension benefits in most European countries.

- Under the current system of labour-tax-based pension finance, labour taxes would increase further, making employment creation less attractive for firms and reducing after-tax wages, potentially reducing further the growth rate of employment and output.

- While there seems to be a political consensus that pension benefits have to be reviewed, to find an agreement on the necessary reform steps seems to be essential.

- Moving partially from the pay-as-you-go system to a pre-funded system may under certain conditions help to guarantee a smooth transformation. But, as we have seen recently, there is also a risk in relying heavily on pension funds that follow high rates of volatility in international financial markets. An alternative direction of improvement could be to move from a labour-tax-based system to a system based on general taxation, implicitly offering a government guarantee for pension benefits.

- In order to use existing resources optimally, broad access to education is necessary. In tertiary education there is a potential for more demand-oriented structures, which would strengthen market mechanisms in Europe.

Finally, these very important issues tread the path to the 2003 East-West conference, which will be a joint conference, in cooperation with the Joint Vienna Institute, devoted to success factors for development in general and to institutions, human capital, educational and training issues in particular. 